\title{
Toulouse, the glorious Athens of the South? Computational analysis of the Salons des Artistes Méridionaux (1907-1939)
}

\author{
Léa Saint-Raymond*1, Solène Amice ${ }^{2}$, Danyl Hadjali ${ }^{3}$, Haythem Hassayoun ${ }^{3}$, Paul \\ Jean $^{4}$, Julien Sentuc ${ }^{5}$, Pavel Soriano ${ }^{6}$, Mathurin Videau ${ }^{5}$, and Yi Zhao ${ }^{3}$ \\ ${ }^{1}$ Observatoire des humanités numériques, ENS-PSL \\ ${ }^{2}$ Université Paris I Panthéon-Sorbonne \\ ${ }^{3}$ ENS-PSL \\ ${ }^{4}$ Ecole du Louvre \\ ${ }^{5}$ Université Paris Dauphine-PSL \\ ${ }^{6}$ Etalab, DINUM, Service du Premier Ministre, Paris
}

April 18, 2021

\begin{abstract}
Created in 1905, the Société des Artistes Méridionaux organized annual exhibitions in Toulouse, in order to promote regional arts and (re)created a "Latin" - and modern - style. Based on a corpus of 11,486 artworks exhibited at the SAM between 1907 and 1939, this paper seeks to measure the contours and particularities of the Salons des Artistes Méridionaux, using a computational approach.
\end{abstract}

From November 23 to December 11, 2021, the 91st Salon des Artistes Méridionaux will be held in Toulouse. This annual exhibition is remarkable for its longevity 1$]$ Since the beginning of the 20th century, it has brought together artists from different backgrounds - painters, sculptors, draughtsmen, decorators, cabinetmakers, etc. The founders of the Société des Artistes Méridionaux, created in Toulouse in 1905, had the ambition to (re)create and promote a "southern style", which would be specific to the South West of France.

This paper seeks to measure the contours and particularities of the Salons des Artistes Méridionaux, using a computational approach. It relies on a database of all the exhibition catalogs of the Salons des Artistes Méridionaux (which will be abbreviated to SAM), from the date of the first accessible catalog -1907- to 1939 ${ }^{2}$ A total of 11,486 numbers exhibited at the SAM was transcribed (a single number may include several artworks), with all the information regarding the exhibitor - first name, name, birth place, awards, status in the SAM, names of professors, address, other biographical information - and all the information about the works - number in the catalog, title, medium, date of creation, sale price / name of the owner, reproduction in the catalog. This database thus allows us to understand the characteristics of SAM between 1907 and 1939, while the current bibliography only considers the artistic life in Toulouse in the broadest sense [2] or the SAM after 1939 [11, 10, 14, 13].

\footnotetext{
*Author of the dataset, teacher at the PSL Master Course (https://data-psl.github.io/intensive-week-dhai/) and responsible for this project, which gathered together the students/co-authors.

1 https://www.artistes-meridionaux.fr/historique.php accessed March 29, 2021.

${ }^{2}$ Most of the catalogues are available online, on the website of the digital and patrimonial library of Toulouse: https://rosalis.bibliotheque.toulouse.fr/, accessed March 29, 2021.
} 
After explaining the objectives of the Artistes Méridionaux, at the time of the creation of their Society and their Salon (section 1), we will see that their initiative corresponded to an economic, artistic and symbolic revenge against the Parisian capital (section 2). Nevertheless, this "southern" affirmation was far from being inclusive: the SAMs were riddled with gender inequalities as well as inequalities between members (section 3 .

\section{1 "For the glory of our region"}

\subsection{An exhibition at the core of Toulouse}

The Société des Artistes Méridionaux was created in 1905, by artists and craftsmen living in Toulouse and coming from different backgrounds : painting (Augustin-Antonin Balon, Georges-François Castex, Paul Costes, Jean Diffre, G.-F. Lineau, André-Pierre Lupiac), sculpture (Auguste Guénot, Louis Oury, Georges Vivent), architecture (Raoul Castan), glassware (Louis-Victor Gesta), but also and above all decorative arts and furniture making (Edmond and Maurice Alet, Paul Balard, René Deflandre, Jean-Germain and Jules Rigal). After a first exhibition in 1906, in a disused chapel located rue de Languedoc, in Toulouse, they chose the Capitole in 1907 in order to display their works (Fig 1) and they started publishing exhibition catalogues.

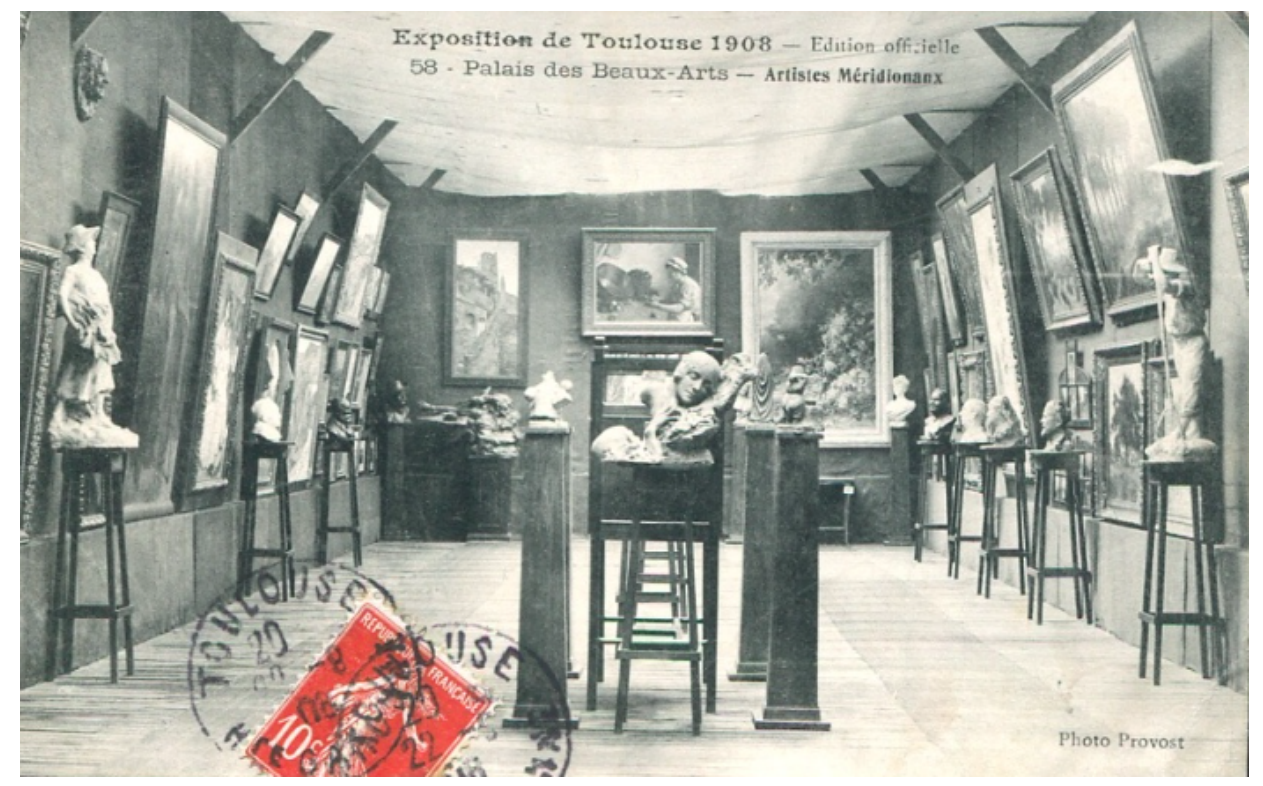

Figure 1: Postcard of the Salon des Artistes Méridionaux in 1908. Coll. L. Saint-Raymond

The choice of this venue is significant. Indeed, the Capitole was - and is still - the emblematic monument of Toulouse. Formerly the home of the "Capitouls" (the consuls of Toulouse), it underwent several phases of construction: its current façade was built in the 18th century and, between the years 1880 and 1898, the municipality launched the creation of four grandiose rooms, including the Galerie des Illustres. In 1907, the Capitole was then a jewel for the arts: in addition to hosting the city hall of Toulouse, the Capitole included a museum with its four reception halls, but also a theater in which the municipal opera performed and which made the reputation of Toulouse as the capital of Bel Canto[4]. By choosing the Capitole, the Artistes Méridionaux sought to position themselves at the heart of the arts in Toulouse. 


\subsection{Tourism and regionalism}

The Société des artistes méridionaux was created at a pivotal moment in the history of Toulouse. At the beginning of the 20th century, this city sought to assert its identity and position itself as the capital of the South-West of France. A strong regionalist movement was born, based on the promotion of the local dialect - Occitan - and on tourism [7. The association Les Toulousains de Toulouse, created in 1904, was the spearhead of this local patriotism, through its newsletter and forum of expression, L'Auta, launched in April 1906 and still active today. This bulletin regularly published the announcements and reports of the SAM. Furthermore, the Les Toulousains de Toulouse founded the Musée du Vieux-Toulouse in 1907, in the Hôtel Dumay, in order to promote the local heritage. ${ }^{3}$

Beyond the actions of the Les Toulousains de Toulouse, the municipality of Toulouse sought to promote local tourism. In 1906, Auguste Guénot, professor of geography and president of the tourist office, coined the term "Ville Rose" to designate Toulouse: this catchy and commercial expression, officially adopted by the city, was used as a slogan on postcards and in all tourist businesses $[3$. At the 1907 SAM, Maurice Alet exhibited a landscape of Toulouse and entitled it "Un coin de la Ville Rose" (A Corner of the Ville Rose). Another sign of the proximity between the SAM and the regionalist promotion was the medal of the Pyrenees Cup, created by Louis Oury and exhibited on the same occasion. The Pyrenees Cup was a great car race, created in 1905: it started from Toulouse and linked, in a loop, all the cities of the Pyrenees, from Perpignan to Biarritz, passing by Foix, Luchon or Pau [7].

The Artistes Méridionaux participated indirectly in the promotion of local tourism, by putting in the center of their works regional places: between 1907 and 1939, the exhibited landscapes privileged the Southwest (Fig 2).

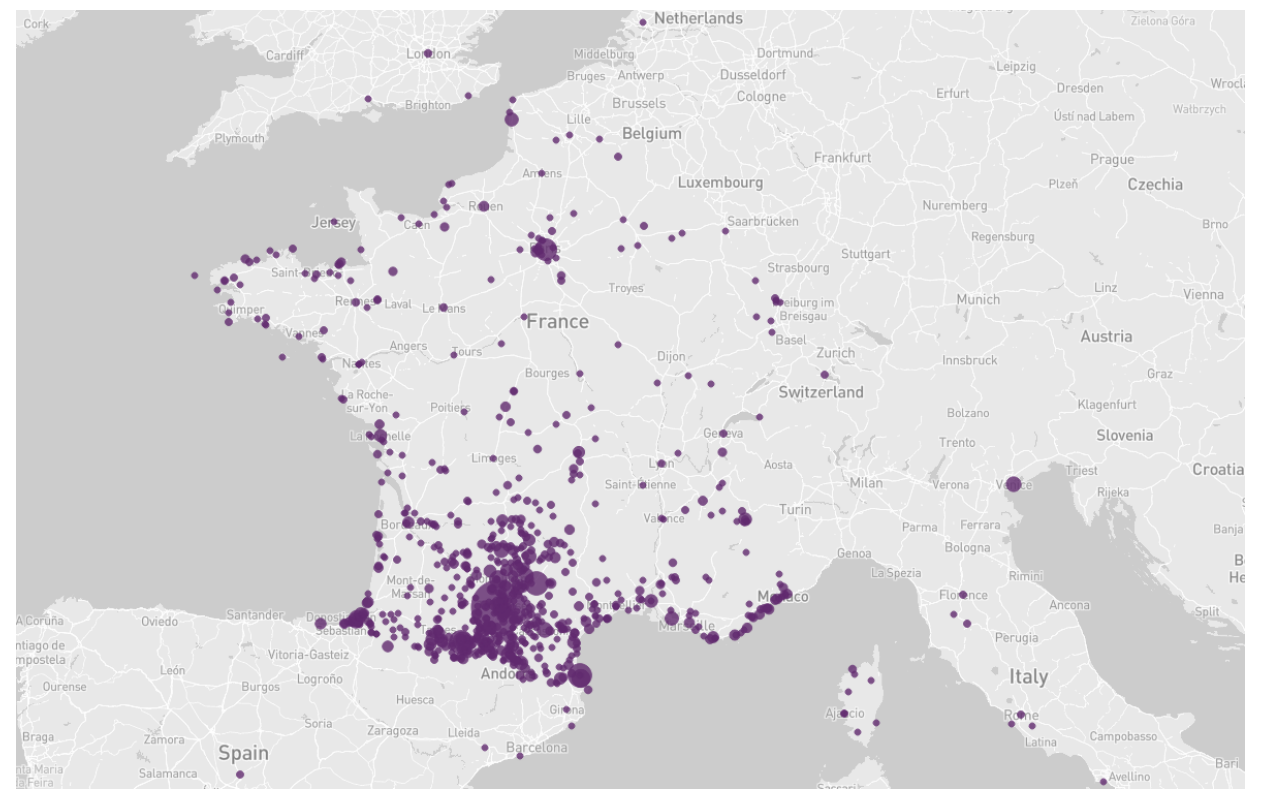

Figure 2: Places represented by the SAM exhibitors individually between 1907 and 1939, regardless of duplicates

Of the 2,984 works exhibited at the SAM, whose title explained the place represented, $59 \%$ concerned places of the Toulouse region (that is, to use an anachronism, places of the Midi-Pyrénées region which existed administratively between the years 1980 and 2016) and 18\%, places of the South-West in the broad sense, that is to say of the Aquitaine region and the Languedoc-Roussillon region. In total, nearly 8 out of 10 identified landscapes were of places in the Southwest. In this corpus, the four most

\footnotetext{
$\sqrt[3]{\text { https://musees-occitanie.fr/musees/musee-du-vieux-toulouse/ }}$ accessed March 29, 2021.
} 
represented places - often reproduced in the illustrated catalogs (Fig 3) - were, in decreasing order, Toulouse (with 468 works exhibited at the SAMs between 1907 and 1939), Saint-Bertrand-de-Comminges (73), Albi (72) and Collioure (60).
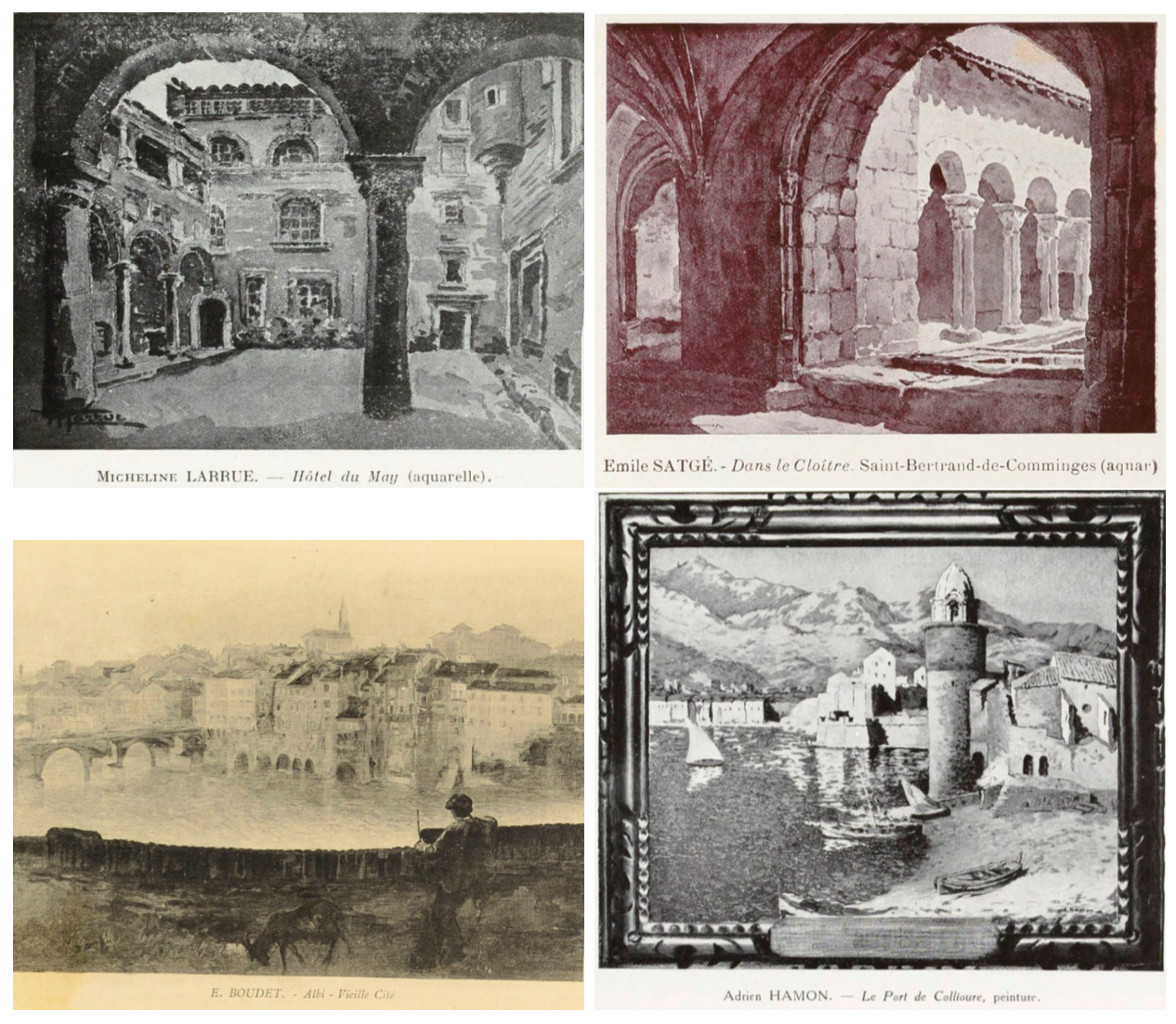

Figure 3: Clockwise: Micheline Larrue, Toulouse, Hôtel du May, watercolor, SAM 1930. Emile Satgé, Dans le Cloître, Saint-Bertrand-de-Comminges, watercolor, SAM 1927. Ernest Boudet, Albi, vieille cité, painting, SAM 1912. Adrien Hamon, Le port de Collioure, painting, SAM 1925.

This geographical anchorage is highlighted in the prefaces of the first catalogs, in which the Artistes Méridionaux claim an "effort towards the beautiful, impregnated with the scents of the soil, [by exhibiting] works which voluntarily reflect the familiar landscapes. "[4 By promoting local landscapes, they sought to contribute to "the glory of our region"5 but, more than that, they sought to revitalize their territory by (re)creating an artistic style that was properly southern.

\subsection{Promoting "Latin" and modern arts}

In the reasoning of the first Artistes Méridionaux, the territory and the local traditions were the basis of a properly modern and "Southern" art. Thus, the SAM exhibitions would contribute to the affirmation of this same artistic style:

We will affirm the will to be of our soil, of our country, to be southerners whatever the cost, to remain in the traditions, the tastes, the customs of our environment, not to look

\footnotetext{
${ }^{4}$ SAM Exhibition Catalogue, 1909, p.5: "effort vers le beau, imprégné des senteurs du terroir, oeuvres qui volontairement reflètent les paysages familiers"

${ }^{5}$ SAM Exhibition Catalogue, 1912, p.14: "la gloire de notre région"
} 
elsewhere, to create, in these conditions, a style ${ }^{6}$

By facilitating the "awakening to modern art of the southern soul" 77 the SAM exhibitions would thus ensure the artistic reputation of Toulouse, and therefore its wealth:

help us to create, to improve, to perfect this Languedoc style that our best hope is to see inscribed on our homes, our furniture, our interiors ... Our beautiful country will gain a little glory, a lot of material wealth, the implementation of energies that are lost, of raw materials helping elsewhere to accomplish what we should do here 8

This promotion of a clean style carries, however, some racist undertones. Also, in the preface of the 1909 catalog, one can read:

The Southern craftsmen and artists are aware that they arrive in their time to fulfill the destinies assigned to our race by translating [...] what the old Latin soul carries in it of taste for the beautiful rhythmic orders and their adaptation to our life.

From this problematic point of view, promoting the "Latin" artworks "grown in southern soil" would prove "to everyone that Toulouse has not degenerated" 10

The definition of what would be a properly southern style was as vague as it was contradictory. The SAM catalogs spoke of a "Latin soul", or of a "Languedoc style" or of a Greek heritage - "Toulouse is the city of arts, the one that proudly claims the glory of the title and the function of Athens of the South", 11 Between Greek and Roman heritage, "Latin", "southern" or "Languedoc" claims, there is enough to be geographically lost. The colophon of the first catalogs also testifies to these artistic contradictions (Fig 4 )

In the center, this colophon draws the silhouette of the Saint-Sernin basilica, jewel of the Southern French Gothic or gothique méridional, also called gothique toulousain and gothique languedocien. Behind the cathedral, the sun - typical of the Toulouse heat! - rises over the city and the intertwined letters S, A and M. Stylized violets surround this landscape - the emblematic flowers of Toulouse. The style of this colophon is openly inspired by the sinuous lines and typography of Art Nouveau, whose centers in France were Paris and Nancy. In order to be "modern", the "southerner" style paradoxically drew its inspiration from the North of France. The Artistes Méridionaux assumed this comparison, wanting to compete with Nancy on the French artistic scene : "As there is the Nancy school, there will be the Languedoc school" 12 The profession of faith of the Artistes Méridionaux thus resembled a declaration of independence, a revanchist emancipation in the art world.

${ }^{6}$ 17 p. 11: "nous y affirmerons la volonté d'être de notre sol, de notre pays, d'être méridionaux coûte que coûte, de rester dans les traditions, les goûts, les moeurso de notre milieu, de ne pas regarder ailleurs, de créer, à ces conditions, un style"

${ }^{7}$ SAM exhibition catalogue, 1909, p.6: "éveil à l'art moderne de l'âme méridionale"

${ }^{8} \mathrm{SAM}$ exhibition catalogue, 1909, p.7: "aidez-nous à créer, à parfaire, à perfectionner ce style languedocien que notre meilleur espoir est de voir inscrit sur nos habitations, nos meubles, nos intérieurs[...]. Notre beau pays en recueillera un peu de gloire, beaucoup de richesses matérielles, la mise en oeuvre d'énergies qui se perdent, de matières premières aidant ailleurs à accomplir ce que nous devrions faire ici.

${ }^{9}$ SAM exhibition catalogue, 1909, p.6: "Les artisans et Artiste Méridionaux ont conscience qu'ils arrivent en leur temps pour accomplir les destinées assignées à notre race en traduisant [...] ce que la vieille âme latine porte en elle de goût pour les belles ordonnances rythmiques et leur adaptation à notre vie"

${ }^{10}[17]$ p. 12 : "nous ferons des choses vivantes, poussées en plein sol méridional, qui prouveront à tous que Toulouse n'a pas dégénéré"

${ }^{11}[17]$ p. 3 : "Toulouse est la ville des arts, celle qui revendique fièrement la gloire du titre et la fonction d'Athènes du Midi."

$12[17]$ p. 11 : "Comme il y a l'école nancéenne, il y aura l'école languedocienne." 


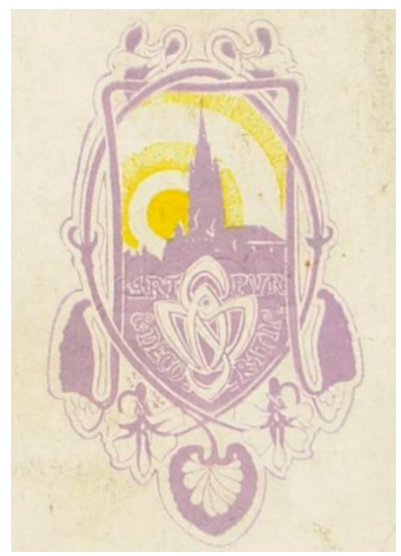

Figure 4: Colophon of the SAM in the 1910 catalogue

\section{A declaration of independence (1907-1909)}

\subsection{Nostalgia of an artistic golden age}

This spirit of revenge was rooted in an idealized past, in this case the 17th and 18th centuries during which the city of Toulouse had its own drawing school, which became the Académie royale de peinture, sculpture et architecture de Toulouse between 1750 and 1793 ([9]). These artistic structures and this environment had no equivalent in France - outside of Paris - and gave a true identity to the école de Toulouse during this period, which can be described as the golden age of Toulouse painting ([16]). Between 1751 and its disappearance in 1793, the Académie royale de peinture, sculpture et architecture de Toulouse organized painting and sculpture exhibitions, called Salons (like the Parisian ones), in order to promote local painters and sculptors. The Salons took place in the Galerie des peintures of the Capitole: not surprisingly, the Artistes méridionaux chose this same prestigious venue to organize their own Salons and to recover the artistic greatness of the city.

In the 19th century, the Académie royale de peinture, sculpture et architecture de Toulouse found an equivalent in the Ecole nationale et spéciale des Beaux-Arts, founded in 1827 in Toulouse, and then from 1883, in the Ecole nationale et spéciale des Beaux-Arts, when the latter came under the supervision of the ministère de l'Instruction publique et des Beaux-Arts. Nevertheless, according to the Artistes méridionaux, this School of Fine Arts did not have the weight to impose a true local artistic identity:

The public is satisfied with local production, and goes to Paris for what is art furniture. The population seems to have a pride in its School of Fine Arts, imposed by a local tradition rather than inspired by the recognition of services rendered; the proof is everywhere 13

Further on, these same artists deplored the flight of their comrades to Paris and the disaffection of the demand for the local production:

Artists live mainly in Paris, and it cannot be denied that those who, for love of their native soil or any other reason, cannot attempt an exodus, have a hard life here. One does not want to know them, one does not trust their work, in their works, one addresses oneself outside, believing that what one asks of them cannot be carried out on the spot ${ }^{14}$

\footnotetext{
13 [17] p.4: "Le public, pour le courant, se contente de la production locale, et s'adresse à Paris pour ce qui est mobilier d'art. La population semble avoir de son Ecole des Beaux-Arts un orgueil plutôt imposé par une tradition locale, qu'inspiré par la reconnaissance des services rendus ; la preuve en est partout"

14 [17] p.7: "Les artistes vivent surtout à Paris, et on ne peut nier que ceux qui, par amour du sol natal ou toute autre raison, ne peuvent tenter l'exode, ont plutôt ici la vie dure. On ne veut pas les connaître, on ne fait pas confiance à leurs travaux, en leurs oeuvres, on s'adresse au dehors, croyant que ce qu'on leur demande ne peut s'exécuter sur place."
} 
The exhibitions of the SAM therefore sought to fight against this Parisian domination, by reintegrating the artists at the local level, by valuing the creations and by giving them a strong artistic identity.

\subsection{Bitterness over Parisian domination}

The bitterness over Parisian domination seemed to implicitly target the Union artistique de Toulouse (which will be shortened to UAT). The first UAT exhibitions took place in Toulouse between 1861 and 1864, then between 1885 and 1909. Founded on the same principle as the "friends of the arts" exhibitions ([12, [6], [5]), the UAT relied on an association of collectors, who jointly purchased the exhibited works - these works being redistributed among the members of the association by drawing lots. According to its statutes, the purpose of the UAT Society was "to encourage, in Toulouse, the progress of the Arts and to propagate the taste for them through public Exhibitions of painting, sculpture, drawing and engraving".

However, this exhibition attached great importance to the Parisian art world. Indeed, the exhibitors had to mention their performances and their awards obtained at the official Parisian Salon. For instance, at the 1907 UAT, Henri Biva mentioned that he had received an "honorable mention" at the 1892 Salon, a 3rd class medal at the 1895 Salon, a 2nd class medal at the 1896 Salon, that he had received a bronze medal at the 1900 Universal Exhibition in Paris and that he was now "hors concours", i.e. exempted from passing before the jury of the Parisian Salon (Fig 5 .

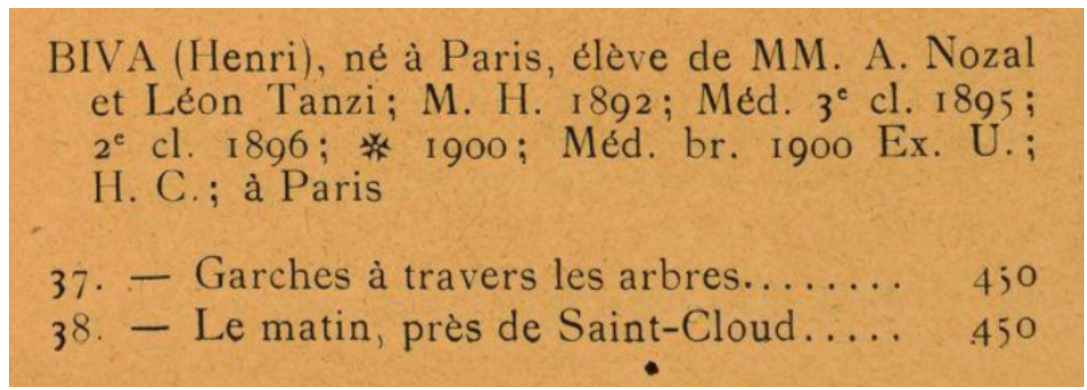

Figure 5: Detail of the catalogue of the Union artistique de Toulouse, 1907, page 21

During three years, the two exhibitions overlapped, in March-April for the UAT, and in May-June for the SAM. It seems that the SAM were held in response to, or even against, the UATs: to test this hypothesis, the last three catalogs of the UAT (1907, 1908 and 1909) were thus transcribed and added to the dataset 15

\subsection{Taking the opposite view of the UAT}

Between 1907 and 1909, the SAMs took the opposite view of the UATs and asserted themselves as a much more local and southern group. The addresses of residence that the artists gave in the catalogs show two very different profiles. During these three years, half of the 655 exhibitors of the UAT came from the Paris region, while the 79 exhibitors of the SAM lived in Toulouse or its surroundings (Fig 6 and Fig 7). The places represented in the exhibited landscapes were equally contrasted: of the 227 works whose title mentioned a precise place at the UAT between 1907 and 1909, only a quarter of them concerned the South-West - Paris, the Côte d'Azur, the Atlantic coast, Brittany and Normandy being widely preferred. On the contrary, the 127 geolocatable works, at the SAM, clearly favored the South-West (Fig 8 and Fig 9). From the point of view of the exhibitors and the exhibited works, the

\footnotetext{
${ }^{15}$ Hadrien Viraben transcribed the 1907 and 1909 UAT catalogues and Léa Saint-Raymond the 1908 one. The authors thank Hadrien Viraben for his contribution.
} 
SAM thus affirmed a much more southern identity, as opposed to the UAT which were much more turned towards Paris

Beyond the geographical and symbolic revenge, the SAMs signed the end of an economic domination against the Parisians who were stepping on their toes in the UAT. On the one hand, the SAM gave more visibility to the artists: the exhibitors were fewer in number - about 30 annual exhibitors at the SAM, compared to about 200 for the UAT - and they showed more works at each exhibition - 2 per exhibitor, on average, for the UAT, compared to 7 to 11, on average, for the SAM.
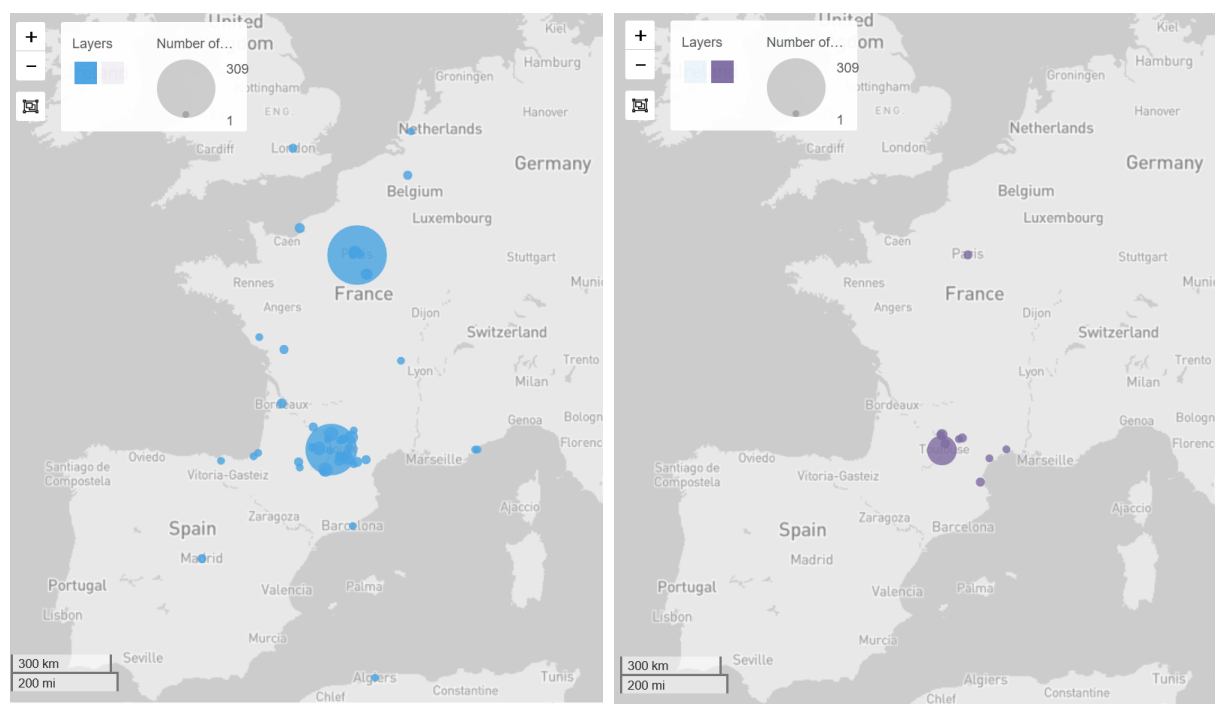

Figure 6: Addresses of the UAT exhibitors (left) and the SAM exhibitors (right) between 1907 and 1909

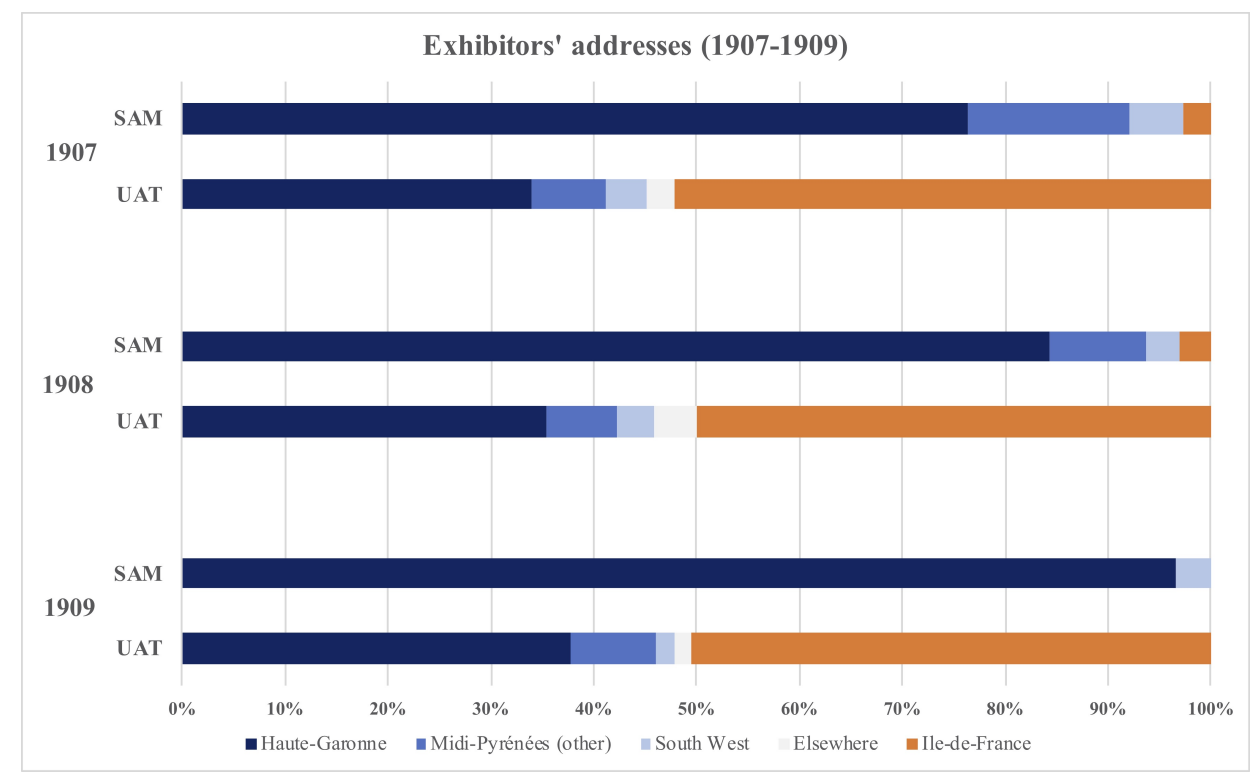

Figure 7: UAT and SAM Exhibitors' addresses 

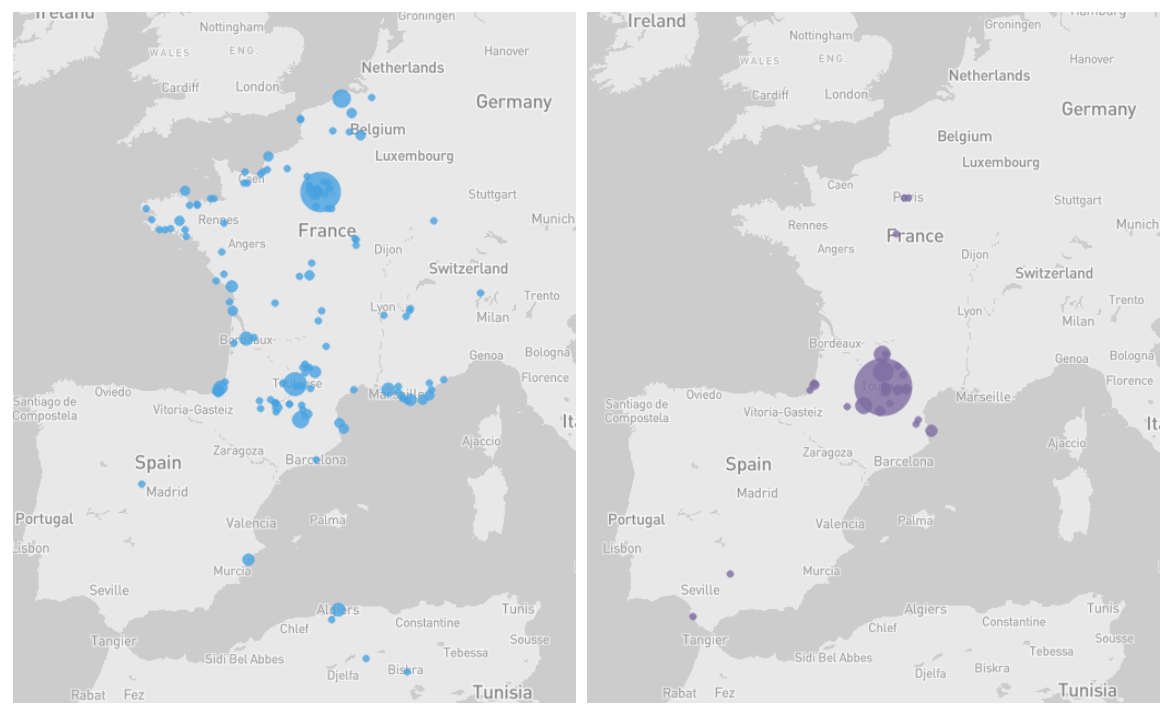

Figure 8: Places represented in the artworks exhibited at the UAT (left) and the SAM (right) between 1907 and 1909

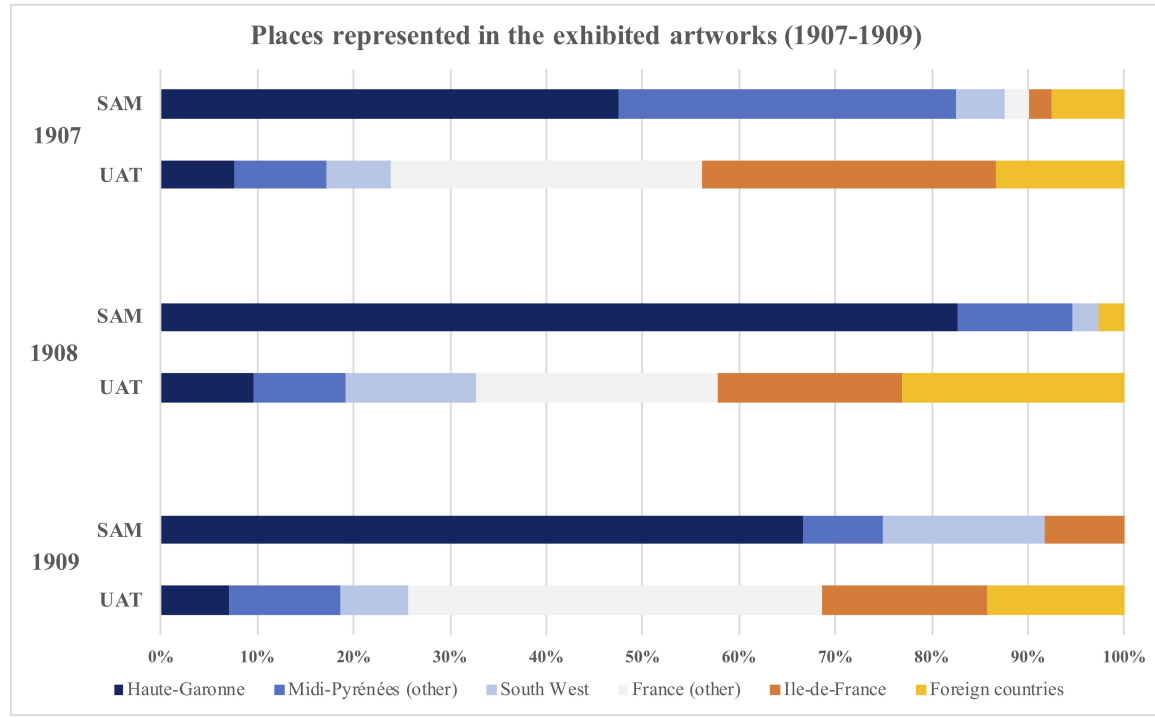

Figure 9: Represented places at the UAT and the SAM

On the other hand, the SAM signaled the end of the economic stigma of Toulouse in the context of art exhibitions. Table 1 in the appendix, details the econometric results of hedonic regressions conducted on the selling price of artworks exhibited between 1907 and 1909 at the SAM or the UAT, and in the right-hand column, for those exhibited at the SAM only. Significantly, artists offered much higher selling prices - 210 francs, on average - when they came from the Paris region. On the other hand, when restricting ourselves to the SAM, this margin ceased to be significant: exhibitors living in Haute-Garonne - i.e. Toulouse and its surroundings - gave significantly higher prices than their comrades, by 11 francs on average.

More anecdotally, the selling price of the catalog was two to four times lower for the SAM: it cost 25 centimes of franc, even illustrated, whereas the catalogs - not illustrated - of the UATs cost 50 centimes without the price of the works, 1 franc with the price. The SAM thus seemed more open to a local 
audience, and in a sense more democratic.

However, this claimed openness masked internal inequalities and fine-grained processes of exclusion, which the computational analysis of the data helps to shed light on.

\section{The underside of the Athens of the South}

\subsection{A man's world?}

In spite of the opening towards southern artists, without distinction, the SAM were at the beginning almost exclusively male (Fig 10p. In 1907, of the 38 exhibitors at the SAM, there was only one woman; the following year, no woman exhibited, and in 1909, one woman exhibited and 28 men. On the contrary, the UAT was much more feminized, with about a quarter of the exhibitors being women.

\begin{tabular}{|c|c|c|c|c|}
\hline Year & Men (UAT) & Women (UAT) & Men (SAM) & Women (SAM) \\
\hline 1907 & 192 & 62 & 37 & 1 \\
\hline 1908 & 169 & 51 & 32 & 0 \\
\hline 1909 & 132 & 49 & 28 & 1 \\
\hline
\end{tabular}

Figure 10: Number of men / women who exhibited at the SAM and the UAT between 1907 and 1909

Only after the war, from 1921-1922, did the number of women increase, both in absolute numbers and in percentage terms, to just under $30 \%$ of exhibitors (Fig 11).

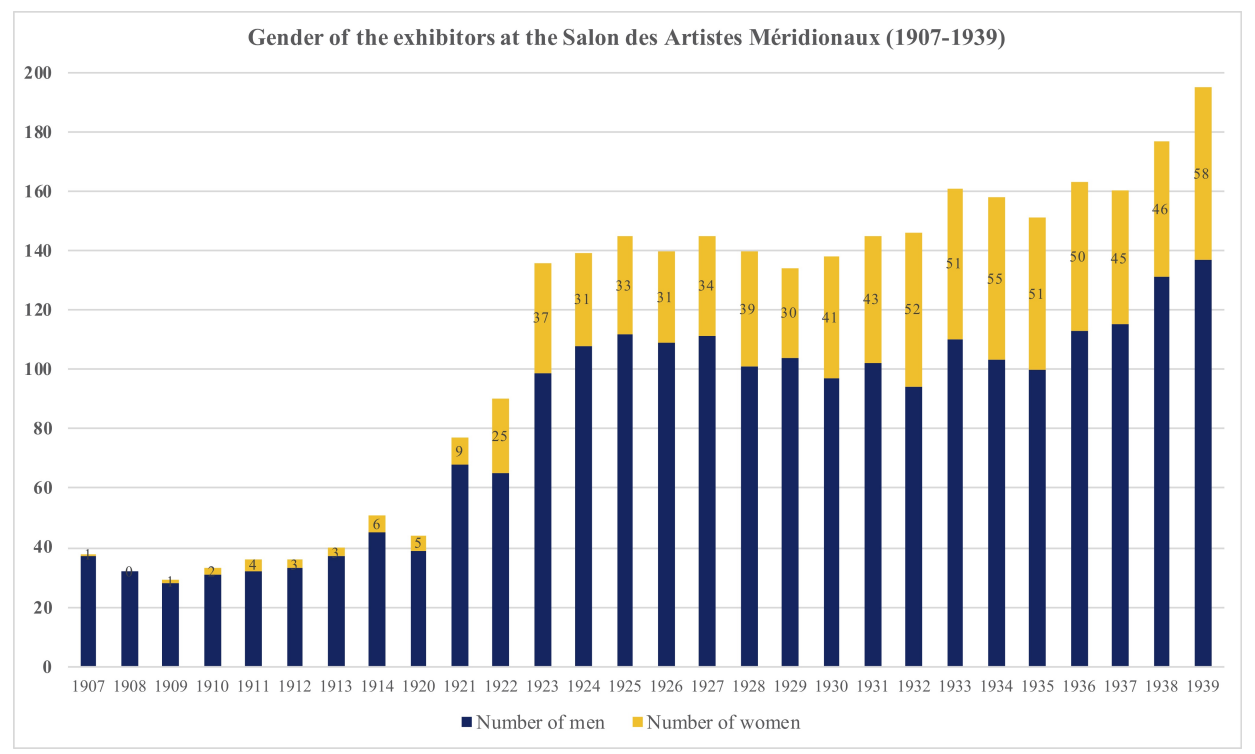

Figure 11: Number of exhibitors of the SAM, depending on their gender

Despite this catch-up, women experienced a higher turnover than men: $40 \%$ of women who exhibited at the ASM participated only once, compared to $35 \%$ of men. Similarly, $55 \%$ of women exhibited once or twice, compared to $50 \%$ of male exhibitors. Similarly, women were in the minority among the "regulars": of the 20 exhibitors who participated in 20 or more Salons, there were only three women, Jeanne Boyé, Pauline Rivière and Hélène Rivière (Fig 12).

Women thus stayed in SAM exhibits for less time than men. Perhaps they felt uncomfortable in this predominantly male environment. Perhaps they did not find it economically beneficial. Indeed, 


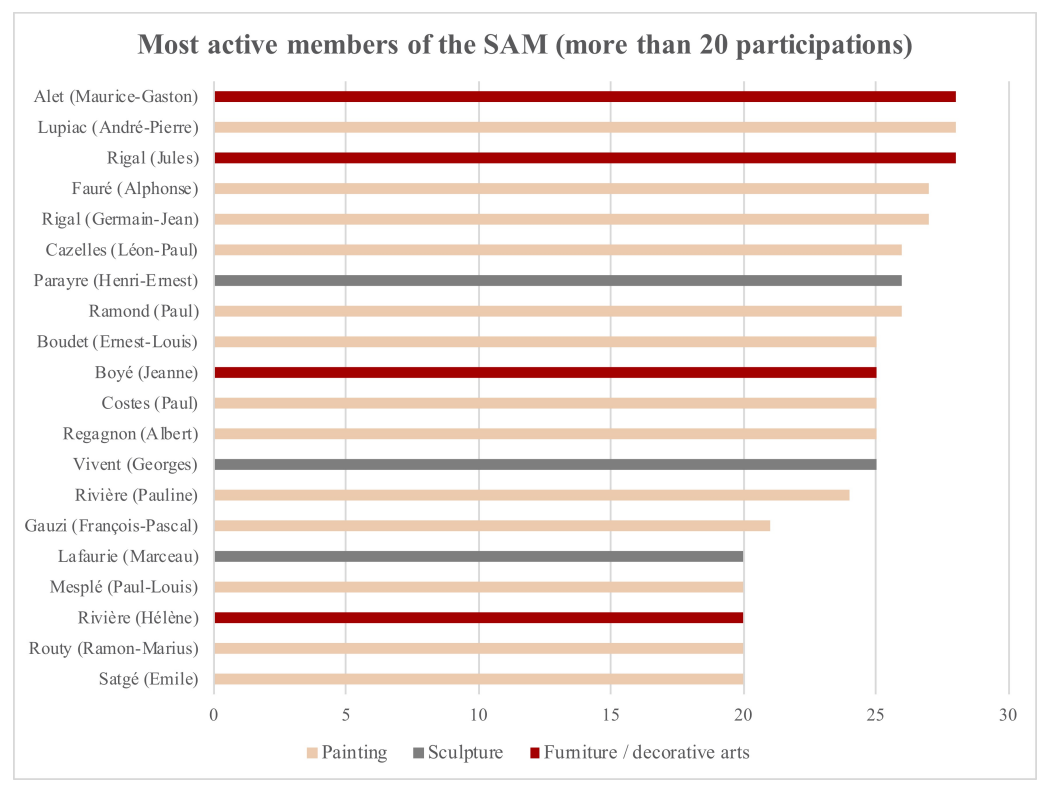

Figure 12: "Regulars" of the SAM who participated in more than 20 exhibitions between 1907 and 1939

between 1907 and 1939, all other things being equal, the selling price of a work created by a woman was significantly lower than that of a work created by a man, even after 1920, a period of greater openness to women (Table 2). This effect of gender remained negative, even when controlling the regression by being a "regular" exhibitor (Table 3) - the fact of being a "regular" had no impact on the selling price.

\subsection{A place for everyone but everyone in his / her medium?}

Gender inequalities hide structural effects. Men and women did not exhibit the same type of works and the mediums were distributed differently (Fig 13 .
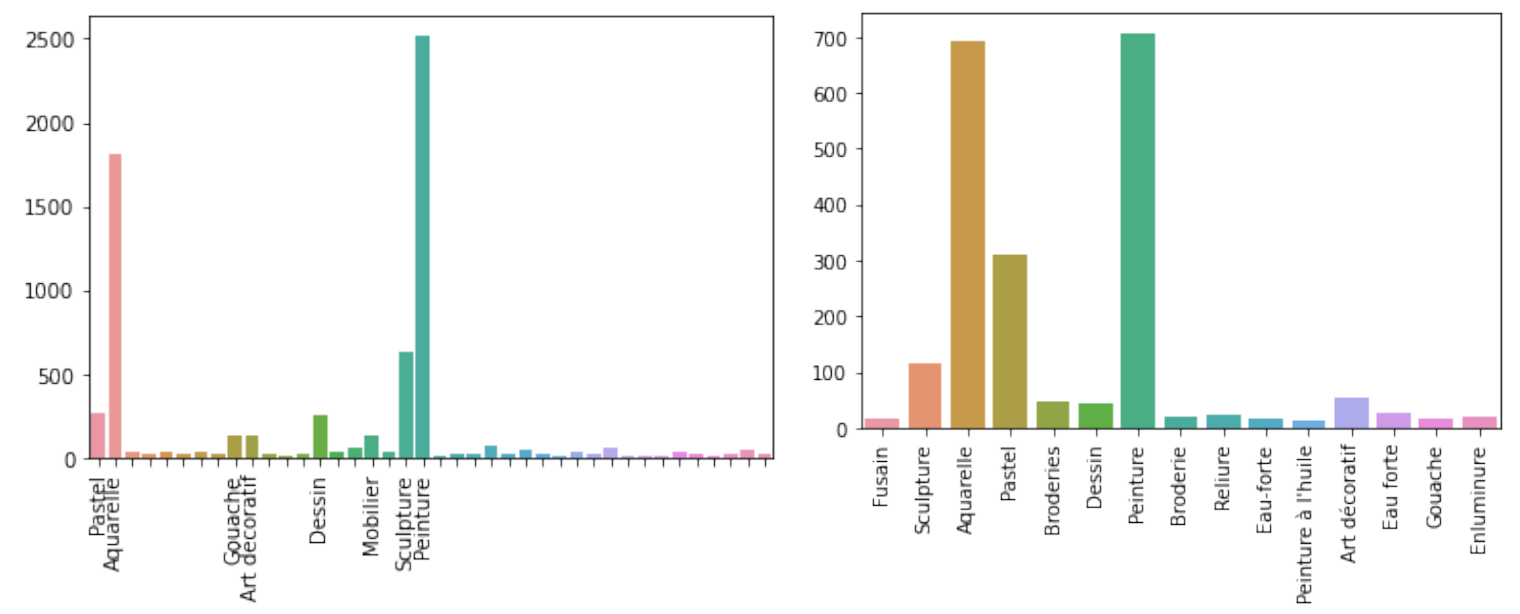

Figure 13: Mediums chosen by men (on the left) and women (on the right) who exhibited at the SAM between 1907 and 1939

While painting and watercolor were the most exhibited mediums for both of men and women, men exhibit more sculptures and drawings and women exhibited more pastels. Among decorative arts, the 
quantitative analysis of titles, through TreeCloud [8] (Fig 14).
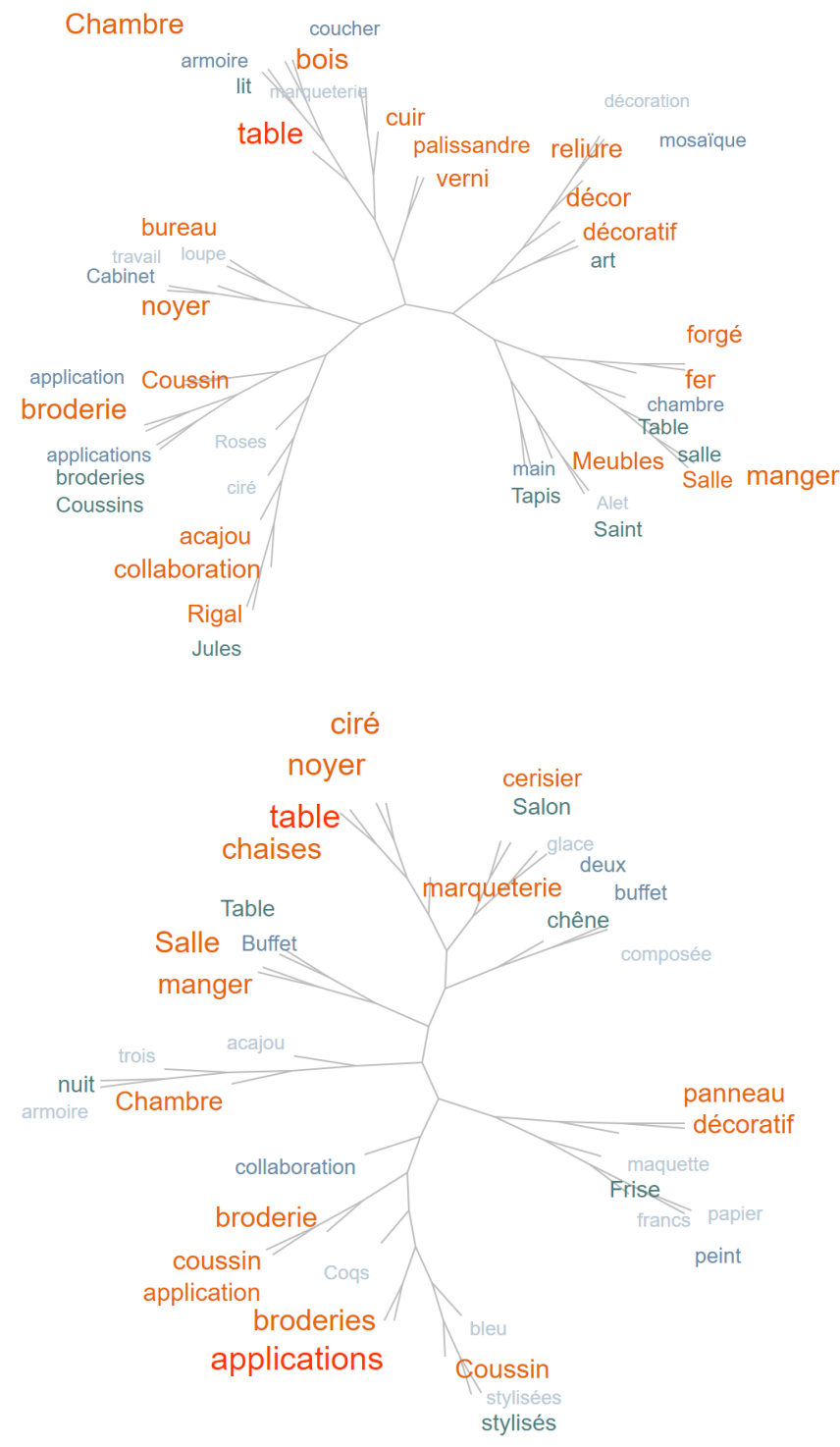

Figure 14: TreeCloud of the decorative art creations exhibited by men (top) and women (bottom) at the SAM, 1907-1939

Despite having a lot in common, for example the passion for "table", "chambre", "broderie", etc., the male and female decorative artists do show differences in interests. Firstly, it is inferred that male artists prefer to master a more diversified field of craftsmanship. "Verni", "ciré", "reliure", "mosaïque", "forgé", "marqueterie", even "broderie", considered feminine in the stereotype, all occupy important places in the title of the male artists. While for their female counterparts, the vocabulary for craftsmanship is much more limited to "ciré", "marqueterie" and "broderie". Besides, in terms of materials, female artists prefer a wide range of ornamental trees like "cerisier", "chêne", etc., whilst male artists frequently includes materials like "fer" and "cuir". It is also interesting to note that female artists really favor the words "stylisé" while the male shows no such tendency at all. They prefer words like "décoratif", 
"décor", which are more neutral.

Finally, men produce more decorative furnitures (like Maurice Alet or Jean-Germain and Jules Rigal) and women exhibit more "embroidered cushions" and ceramics. Indeed, Pauline Rivière, the first woman who exhibited at the SAM, in 1907, showed cushions, collar and screen with embroidered patterns. Similarly, Madeleine Bijon-Cathary exhibited many paintings from 1928 through 1939 but the only works that were reproduced in the catalogue were the Art Deco ceramics she displayed during the first three years of her participation (Fig 15).

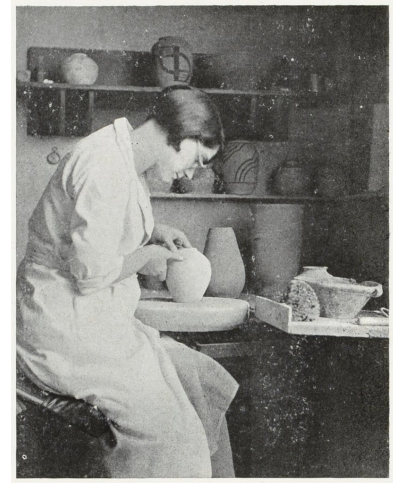

Atelier de céramique de MadBLine BIJON-CATHARY.

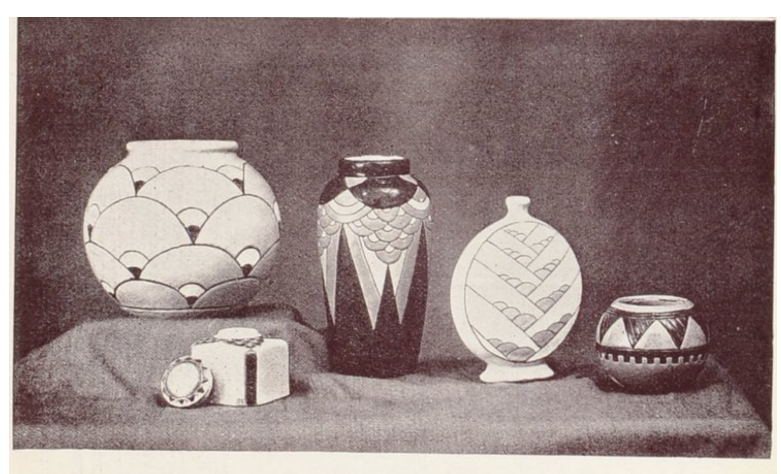

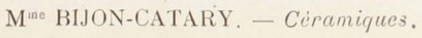

Figure 15: Madeleine Bijon-Cathary's ceramic workshop and ceramics, reproduced in the 1930 and 1928 SAM catalogues

The SAM thus maintained a gendered division of artworks, while advocating a unique, "southern" and modern art.

\subsection{A closed environment?}

It is difficult to assess whether the SAM constituted a closed environment: to do so, one would have to measure the participation of all exhibitors in all existing exhibitions during the same period, from 1907 to 1939. Nevertheless, it is possible to understand this openness/closure from the database.

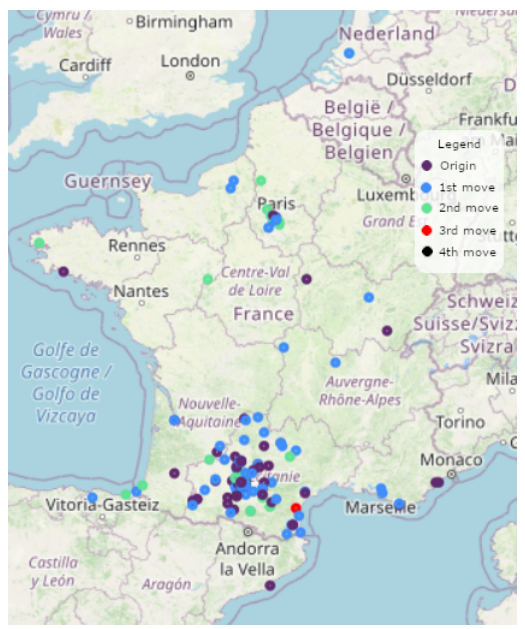

Figure 16: The successive moves of the exhibitors at the SAM (1907-1939)

Exhibitors' moves are a first way of understanding this aspect. The cartography of successive moves (Fig 16) shows the importance of the South-West: very few exhibitors at the SAM "went up 
to Paris". On the contrary, most of them stayed in a perimeter close to Toulouse, indicating a very strong attachment to this region. This local anchorage is all the more visible in the choice of the new exhibition place: from 1920 onwards, all the SAM took place in the "Palais des Arts", i.e. in a $300 \mathrm{~m}^{2}$ room located in the west wing of the Ecole des Beaux-Arts, built between 1892 and 1895[16 Unlike the Capitole, which, because of its political dimension, was open and accessible to all, this new venue seemed reserved for a small world of art insiders, or at least more confidential.

Another indicator allows us to understand the routine - and therefore rather closed - aspect of an exhibition: the presence of a reproduction in the catalog, which was a kind of privilege granted to the creator of the work in question. Indeed, an artwork reproduced by photo-engraving has more visual impact on the visitors of the SAM, also leaving a trace in libraries and memories, even after the end of the exhibition. The logistic regression in Table 4 highlights the determinants that, in probability, increased the chances of an artwork being reproduced in the catalog. The results are striking: only the fact of being a "regular" in the strict sense - more than 20 participations - or in the broader sense - more than 17 participations - significantly increased the probability of this privilege. The emblematic example is Maurice-Gaston Alet, who exhibited the most (Fig 12) and whose furniture was almost systematically reproduced in the catalogs. There seemed to be two speeds between the one-shot exhibitors and the "regulars".

Finally, the structure of the art market in Toulouse allows us to measure the economic openness of the SAM: was there a national or international pool of collectors who lent works at these events? Did the SAM mobilize local, national or international art dealers? On this last point, it is striking to note the absence of dealers as intermediaries. The SAM catalogs made no mention of works lent or put up for sale by dealers, nor did they mention any artist who would give his or her address in a gallery.

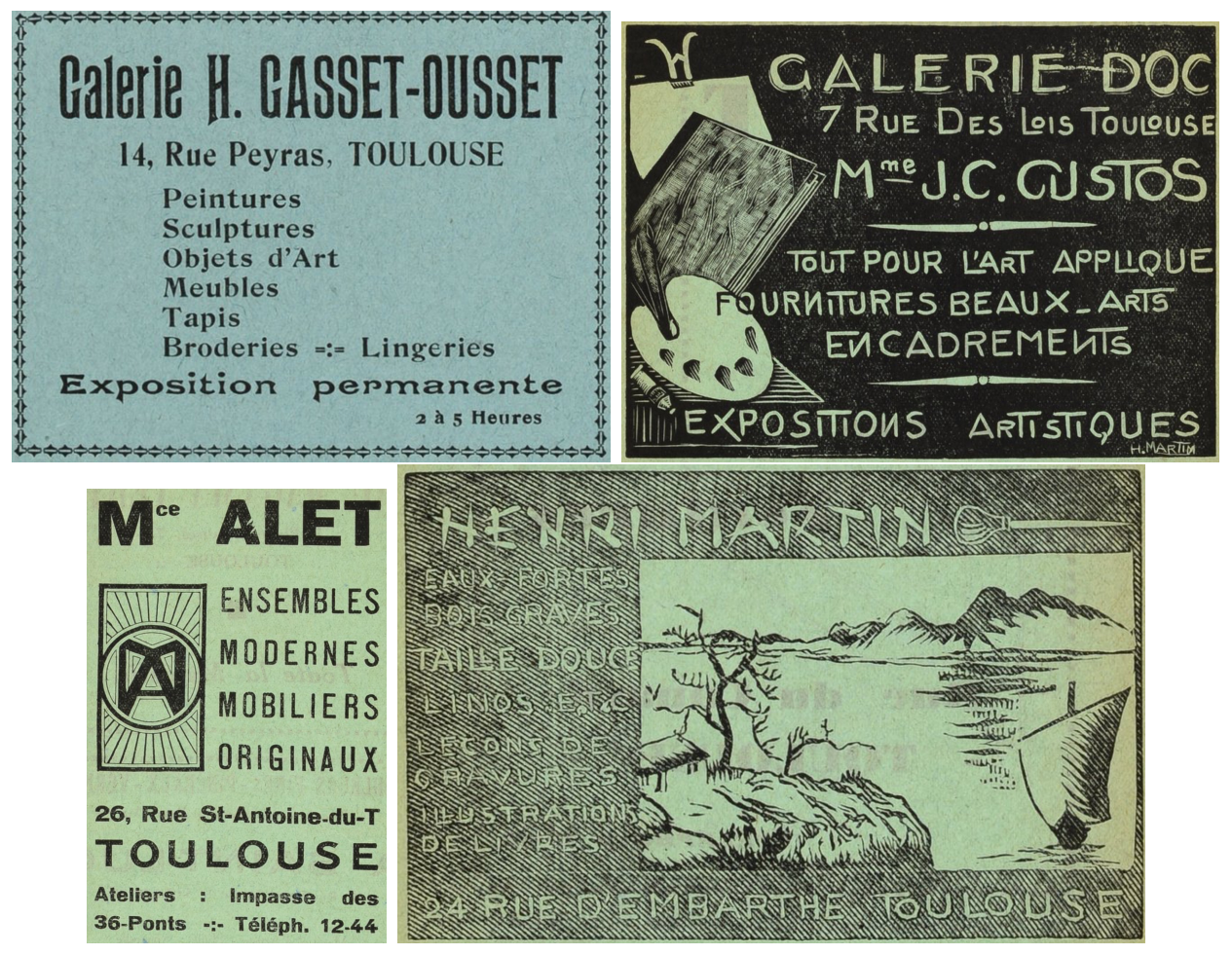

Figure 17: Advertisements of Hélène Gasset-Ousset's, Juliette Gustos's, Maurice Alet's and Henri Martin's own galleries in Toulouse, in the 1927 and 1934 SAM catalogues

Nevertheless, a few Artistes méridionaux represented themselves, in their own art galleries, like

${ }^{16}$ http://isdat.fr/beaux-arts/presentation/, accessed April 1, 2021. 
Maurice Alet ([18]), Hélène Gasset-Ousset, Juliette Gustos and Henri Martin. They did not hesitate to advertise their business in the pages of catalogs (Fig 17). This is an important feature of the Toulouse art world. Indeed, when comparing the SAM with another exhibition in another southern city - the AIB, Artistes Indépendants Bordelais, active from 1928 in Bordeaux - the exhibitors of the AIB were either not represented by any local art gallery (there were only restorers of paintings) or they were represented by a Parisian dealer [15].

On the supply side, the art market in Toulouse was thus characterized by the adage "help yourself and Heaven will help you" (aide-toi et le Ciel t'aidera). On the demand side, were there enough collectors to support local production? The catalogs of the SAM give a first answer, as they mention the name of the collector, when the latter lent a work which belonged to him or her: the following network (Fig 18) represents the links between the collectors and the collected artists-exhibitors.

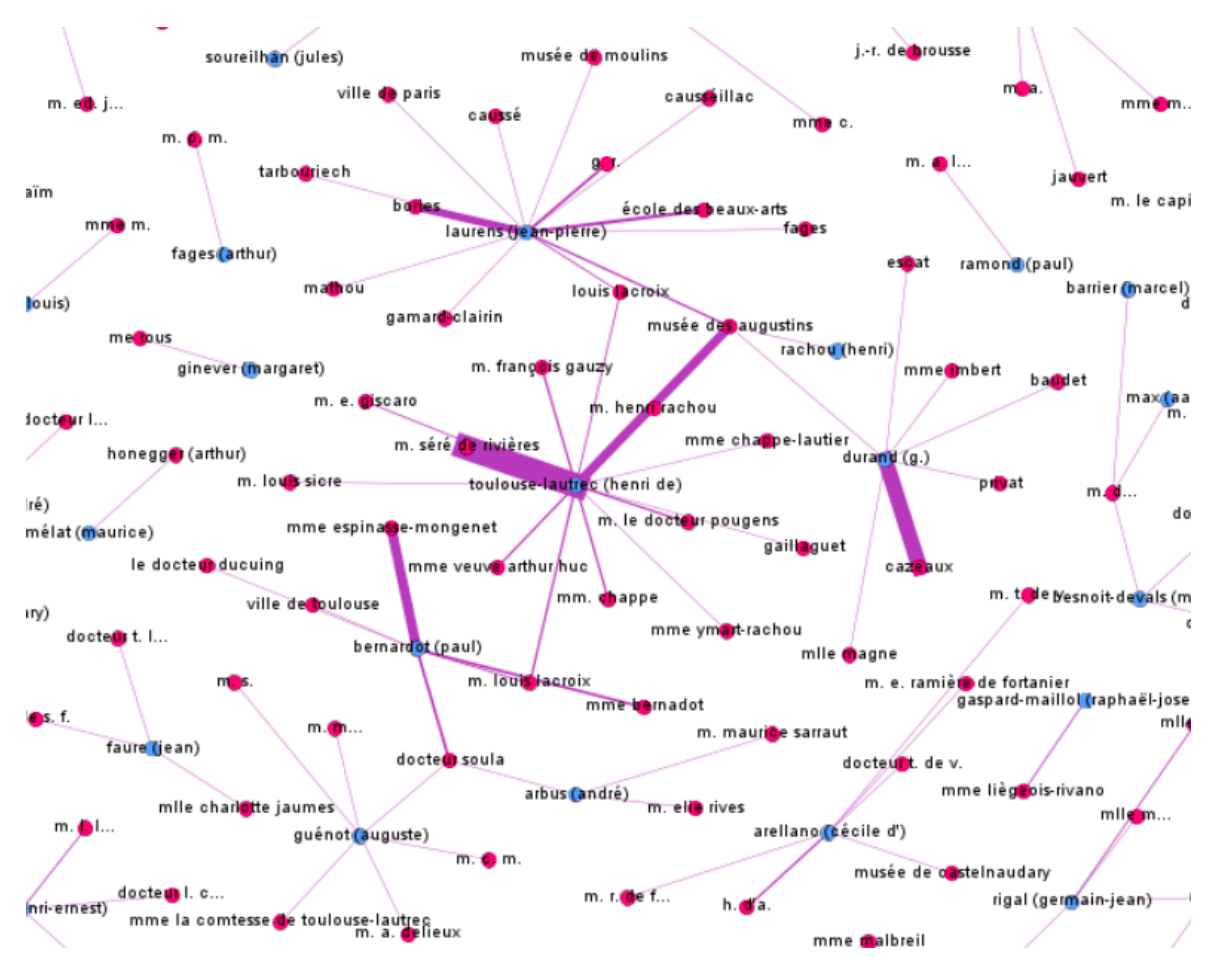

Figure 18: Detail of the network between collectors and collected artists, for the works exhibited at the SAM between 1907 and 1939

Most collectors hid behind an anonymous name, which makes identification impossible and therefore doubtful - perhaps the artist was hiding behind this mysterious name. Three collectors - only! - stood out in this network, by their willingness to reveal their names and therefore their patronage, and by the - quite relative - frequency of their loans: Louis Lacroix (president of the Académie de Arts de Toulouse), Dr. Camille Soula and Dr. Joseph Ducuing. Nevertheless, their choices were very selective. Louis Lacroix loaned works by well-known and deceased Toulouse artists - Jean-Paul Laurens and Henri de Toulouse-Lautrec - and two drawings by Paul Bernardot. Dr. Soula lent works by André Arbus, Auguste Guénot and Paul Bernardot and Dr. Ducuing, a work by Paul Bernardot. These three patrons officially supported a very small number of southern artists, or even a single artist (Paul Bernardot). This clique effect is made visible in two frescoes of the Parnasse occitan (Fig 19), created by Marc Saint-Saëns in 1934-1935 to decorate the new library in Toulouse 17

\footnotetext{
${ }^{17}$ https://www.archives.mairie-toulouse.fr/web/guest/histoire-de-toulouse/lieux/bibliotheque-du-
} patrimoine/parnasse-occitan/ accessed April 1, 2021. 

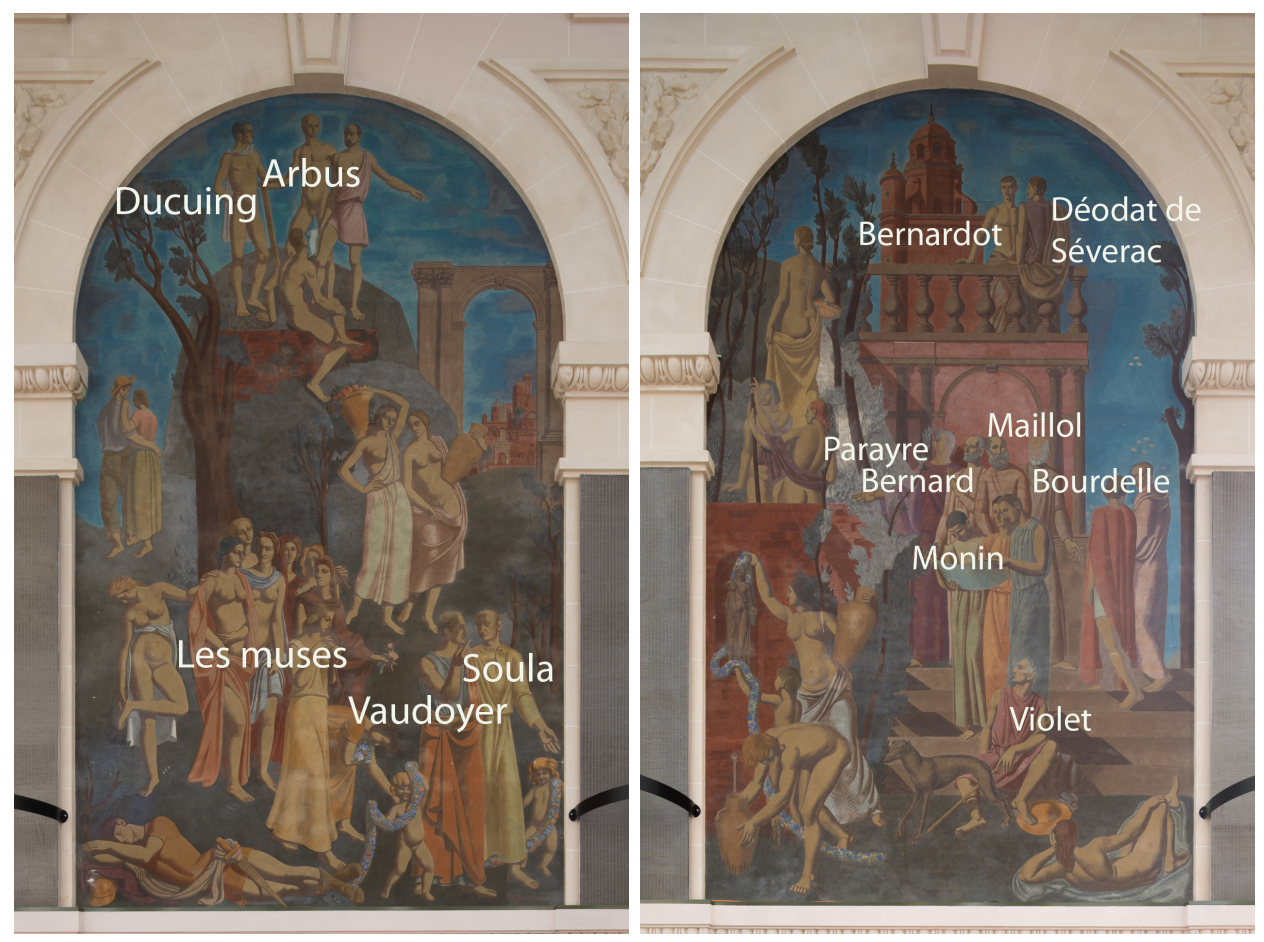

Figure 19: Details of the Parnasse occitan, created by Marc Saint-Saëns in 1934-1935, Bibliothèque du Périgord, Toulouse, with the names of the characters

In this work, the two friends Joseph Ducuing and Camille Soula are represented jointly - the former was the latter's student at the Toulouse medical school [1] - with the artists of their collection, André Arbus and Paul Bernardot. Another regular of the SAM, the sculptor Henry Parayre, was also painted by Marc Saint-Saëns, who was none other than Joseph Ducuing's son-in-law. This fresco thus testifies to the selectivity of this network of collector-patrons, and to a very important clique effect.

\section{Conclusion}

A computational analysis thus made it possible to identify some characteristics of the SAM: a very strong anchoring in the local space, a detachment from the UATs which were too dominated by Paris, but also a certain form of machismo and, in fine, a milieu which was rather closed to a few privileged regulars and a few equally selective collectors-patrons.

These temporary conclusions must be subjected to further research, in the archives and reserves of museums - Musée des Augustins, Musée du Vieux-Toulouse. They will also benefit from being compared to other exhibitions that took place at the same time as the SAM, in order to test the degree of openness of the exhibitors and their commercial strategies, but also to the UAT (whose corpus has been constituted with Hadrien Viraben). Last but not least, this first step will be followed by the meticulous research of the works exhibited at the SAM.

The analysis of the Toulouse art world is part of a larger research project - DatART - led by Léa Saint-Raymond and hosted at the ENS-PSL Observatoire des humanités numériques. By making available data from the SAM, the UAT and the AIB of Bordeaux, it will allow us to understand the regional logics at work in the art world and to reconnect this history with the local artistic and cultural heritage. 


\section{Appendix}

Table 1: Hedonic regression of the price of the artworks exhibited at the SAM and the UAT, between 1907 and 1909, in constant 1907 francs

\begin{tabular}{|c|c|c|}
\hline Variable & 1907-1909 SAM UAT & 1907-1909 SAM \\
\hline UAT & $\begin{array}{l}29.4 \\
(2.8)\end{array}$ & \\
\hline Woman & $\begin{array}{c}-46.9 \text { *** } \\
(37.7)\end{array}$ & dropped \\
\hline Still life & $\begin{array}{l}-67.1 \\
(38.4)\end{array}$ & $\begin{array}{c}33.9 \\
(92.9)\end{array}$ \\
\hline Landscape & $\begin{array}{c}-64.7 * * \\
(22.7)\end{array}$ & $\begin{array}{l}-43.6 \\
(38.3)\end{array}$ \\
\hline Portrait & $\begin{array}{c}124.4^{* *} \\
(40.3)\end{array}$ & $\begin{array}{c}193.1 \text { ** } \\
(64.9)\end{array}$ \\
\hline Painting & $\begin{array}{l}-97.9 \\
(60.8)\end{array}$ & $\begin{array}{c}-242.4^{* *} \\
(82.8)\end{array}$ \\
\hline Sculpture & $\begin{array}{c}-210.6 * * \\
(67.5)\end{array}$ & $\begin{array}{c}-329.3 \text { *** } \\
(92.4)\end{array}$ \\
\hline Graphic art & $\begin{array}{c}-233.2^{* * *} \\
(66.9)\end{array}$ & $\begin{array}{c}-359.5 \text { *** } \\
(90.5)\end{array}$ \\
\hline Engraving & $\begin{array}{c}-381.4^{* * * *} \\
(89.3)\end{array}$ & $\begin{array}{c}-370.7 * * \\
(141.6)\end{array}$ \\
\hline Haute-Garonne & $\begin{array}{l}-18.6 \\
(37.6)\end{array}$ & $\begin{array}{c}10.7 * * * \\
(55.0)\end{array}$ \\
\hline Midi-Pyrénées & $\begin{array}{c}5.9 \\
(61.5)\end{array}$ & $\begin{array}{l}-28.2 \\
(177.3)\end{array}$ \\
\hline Aquitaine & $\begin{array}{c}12.7 \\
(151.4)\end{array}$ & dropped \\
\hline Ile-de-France & $\begin{array}{c}209.7^{* * *} \\
(52.2)\end{array}$ & $\begin{array}{c}115.2 \\
(221.9)\end{array}$ \\
\hline Constant & $\begin{array}{c}327.1 \text { *** } \\
(82.2)\end{array}$ & $\begin{array}{l}451.6 \text { * } \\
(188.1)\end{array}$ \\
\hline $\mathrm{Nb}$ of obs & $? ? ?$ & $? ? ?$ \\
\hline Multiple $\mathrm{R}^{2}$ & 0.1237 & 0.0485 \\
\hline Adjusted $\mathrm{R}^{2}$ & 0.1162 & 0.0337 \\
\hline
\end{tabular}

${ }^{* * *} p<0.01,{ }^{* *} p<0.05,{ }^{*} p<0.1$. 
Table 2: Hedonic regression of the price of the artworks exhibited at the SAM between 1907 and 1939 , in constant 1907 francs

\begin{tabular}{ccc}
\hline Variable & $\mathbf{1 9 0 7 - 1 9 3 9}$ SAM & 1920-1939 SAM \\
\hline Woman & $-173.7^{* * *}$ & $-45.1^{* * *}$ \\
Still life & $(48.5)$ & $(7.2)$ \\
& 51.6 & -21.2 \\
Landscape & $(47.4)$ & $(12.3)$ \\
& -33.0 & $-32.4^{* * *}$ \\
Portrait & $(24.3)$ & $(6.7)$ \\
& $127.6^{* *}$ & 3.6 \\
Painting & $(45.3)$ & $(21.0)$ \\
& $-242.4^{* * *}$ & $-60.3^{* *}$ \\
Sculpture & $(52.7)$ & $(18.5)$ \\
& $-337.2^{* *}$ & $-68.3^{* *}$ \\
Graphic art & $(60.0)$ & $(24.4)$ \\
& $-352.4 * * *$ & $\left(146.4^{* * *}\right.$ \\
Engraving & $(57.3)$ & $-176.0^{* * *}$ \\
& $-352.9 * * *$ & $(23.8)$ \\
Haute-Garonne & $(98.9)$ & $-15.7^{* * *}$ \\
& 46.1 & $(8.2)$ \\
Midi-Pyrénées & $(31.9)$ & $38.4 * *$ \\
& -75.9 & $(12.7)$ \\
Aquitaine & $(68.3)$ & 39.2 \\
& dropped & $(23.5)$ \\
Ile-de-France & 89.6 & 65.7 \\
& $(113.6)$ & $(17.9)$ \\
Constant & 469.8 & $200.6^{* * *}$ \\
& $(81.3)$ & $(20.2)$ \\
Nb of obs & $? ? ?$ & $? ? ?$ \\
Multiple ${ }^{2}$ & 0.0605 & 0.1202 \\
Adjusted $\mathrm{R}^{2}$ & 0.0511 & 0.1164 \\
\hline
\end{tabular}

$$
\text { *** } p<0.01,{ }^{* *} p<0.05, * p<0.1 \text {. }
$$


Table 3: Hedonic regression of the price of the artworks exhibited at the SAM between 1907 and 1939 , in constant 1907 francs

\begin{tabular}{|c|c|c|}
\hline Variable & 20 participations or more & 17 participations or more \\
\hline \multirow[t]{2}{*}{20 participations or more } & 16.4 & - \\
\hline & $(10)$ & - \\
\hline \multirow[t]{2}{*}{17 participations or more } & - & 20.5 \\
\hline & - & $(9.6)$ \\
\hline \multirow[t]{2}{*}{ Woman } & $-66.2^{* * *}$ & $-69.3^{* * *}$ \\
\hline & $(10)$ & $(10)$ \\
\hline \multirow{2}{*}{ Still life } & $-29.2^{*}$ & $-27.7^{*}$ \\
\hline & $(14.9)$ & $(14.9)$ \\
\hline \multirow[t]{2}{*}{ Landscape } & $-42^{* * *}$ & $-42^{* * *}$ \\
\hline & $(8.4)$ & $(8.4)$ \\
\hline \multirow{2}{*}{ Portrait } & $66.7 * * *$ & $67.2^{* * *}$ \\
\hline & $(20.2)$ & $(20.2)$ \\
\hline \multirow[t]{2}{*}{ Painting } & $-90.8^{* * *}$ & $88.1 * * *$ \\
\hline & $(8.6)$ & $(22.6)$ \\
\hline \multirow[t]{2}{*}{ Sculpture } & $-31 * *$ & $-68.3 * *$ \\
\hline & $(27.1)$ & $(27)$ \\
\hline \multirow[t]{2}{*}{ Graphic art } & $-199 * * *$ & $-201.1 * * *$ \\
\hline & $(27.1)$ & $(23.3)$ \\
\hline \multirow[t]{2}{*}{ Engraving } & $-164.2^{* * *}$ & $-247.7 * * *$ \\
\hline & $(27.1)$ & $(30.9)$ \\
\hline \multirow[t]{2}{*}{ Haute-Garonne } & -6.3 & -8.2 \\
\hline & $(11.2)$ & $(11.3)$ \\
\hline \multirow[t]{2}{*}{ Midi-Pyrénées } & -12.6 & 14.7 \\
\hline & $(17.6)$ & $(17.6)$ \\
\hline \multirow[t]{2}{*}{ Aquitaine } & 23.5 & 26.5 \\
\hline & $(35.4)$ & $(35.4)$ \\
\hline \multirow[t]{2}{*}{ Ile-de-France } & $233.7^{* * *}$ & $236^{* * *}$ \\
\hline & $(17.5)$ & $(17.6)$ \\
\hline \multirow[t]{2}{*}{ Constant } & $274^{* * *}$ & $273^{* * *}$ \\
\hline & $(26)$ & $(26)$ \\
\hline $\mathrm{Nb}$ of obs & $? ? ?$ & $? ? ?$ \\
\hline Multiple $\mathrm{R}^{2}$ & 0.0605 & 0.1202 \\
\hline Adjusted $\mathrm{R}^{2}$ & 0.0511 & 0.1164 \\
\hline
\end{tabular}

*** $p<0.01, * * p<0.05, * p<0.1$. 
Table 4: Logistic regression of reproduced artworks exhibited at the SAM between 1907 and 1939

\begin{tabular}{|c|c|c|}
\hline Variable & 20 participations or more & 17 participations or more \\
\hline 20 participations or more & $\begin{array}{c}0.8274^{* * *} \\
(0.1823)\end{array}$ & \\
\hline 17 participations or more & & $\begin{array}{c}0.7031 \text { *** } \\
(0.1686)\end{array}$ \\
\hline Woman & $\begin{array}{c}-0.4099 * \\
(0.2052)\end{array}$ & $\begin{array}{c}0.1966 \\
(0.2066)\end{array}$ \\
\hline Constant Price & $\begin{array}{c}7.195 e-04^{* * *} \\
(1.994 \mathrm{e}-04)\end{array}$ & $\begin{array}{c}7.031 e-04^{* * *} \\
(1.970 \mathrm{e}-04)\end{array}$ \\
\hline Landscape & $\begin{array}{c}-3.178 \mathrm{e}-02 \\
(0.1845)\end{array}$ & $\begin{array}{c}-3.313 \mathrm{e}-02 \\
(0.1841)\end{array}$ \\
\hline Portrait & $\begin{array}{l}-1.528 \\
(0.8795)\end{array}$ & $\begin{array}{l}-1.1515 \\
(0.8728)\end{array}$ \\
\hline Painting & $\begin{array}{c}0.3560 \\
(0.4881)\end{array}$ & $\begin{array}{c}0.3242 \\
(0.4884)\end{array}$ \\
\hline Sculpture & $\begin{array}{c}0.3929 \\
(0.6060)\end{array}$ & $\begin{array}{c}0.3065 \\
(0.6068)\end{array}$ \\
\hline Graphic art & $\begin{array}{c}0.4148 \\
(0.5058)\end{array}$ & $\begin{array}{l}-0.2603 \\
(0.5067)\end{array}$ \\
\hline Engraving & $\begin{array}{c}0.2632 \\
(0.7043)\end{array}$ & $\begin{array}{c}0.1568 \\
(0.7054)\end{array}$ \\
\hline Still-life & $\begin{array}{c}0.198 \\
(0.2996)\end{array}$ & $\begin{array}{c}0.2835 \\
(0.2993)\end{array}$ \\
\hline Midi-Pyrénées & $\begin{array}{l}0.6208 \\
(1.016)\end{array}$ & $\begin{array}{l}0.5863 \\
(1.017)\end{array}$ \\
\hline Aquitaine & $\begin{array}{l}-12.53 \\
(31.51)\end{array}$ & $\begin{array}{l}-12.48 \\
(31.55)\end{array}$ \\
\hline Ile-de-France & $\begin{array}{l}0.2282 \\
(1.167)\end{array}$ & $\begin{array}{l}0.2405 \\
(17.7)\end{array}$ \\
\hline Constant & $\begin{array}{c}-4.592^{* * *} \\
\quad(1.120)\end{array}$ & $\begin{array}{c}-4.487^{* * *} \\
\quad(1.120)\end{array}$ \\
\hline $\mathrm{AIC}$ & 1315.1 & 1312.9 \\
\hline
\end{tabular}

Acknowledgement. This paper is the outcome of the PSL Master Course in Digital Humanities and Artificial Intelligence, organized by the DHAI team between March 29 and April 2, 2021 (https://datapsl.github.io/intensive-week-dhai/). It allowed students to learn about computational data analysis and to carry out this project, under the supervision of Léa Saint-Raymond. The authors thank Gabriel Peyré, for organizing the DHAI Master Course, and Hadrien Viraben, for providing the dataset of the 1907 and 1909 UAT exhibition catalogs. 


\section{References}

[1] Jacques Arlet. Des Toulousains remarquables. Toulouse, Loubatières, 2002.

[2] Luce Barlangue. La vie artistique à Toulouse 1888-1939. unpublished Ph. D, Université Toulouse Le Mirail, 1989.

[3] Luce Barlangue. L’invention du surnom de "toulouse ville rose". Méridiennes, 2009.

[4] Aurélien Borot. Chanter à toulouse sous l'occupation. In Toulouse, une métropole méridionale: vingt siècles de vie urbaine, pages 807-818, 2009.

[5] Nicolas Buchaniec. Salons de province : Les expositions artistiques dans le nord de la France (1870-1914). Rennes, PUR, 2010.

[6] Dominique Dussol. Art et bourgeoisie. La Société des amis des arts de Bordeaux (1851-1939). Bordeaux, Le Festin / Atelier du CERCAM, 1997.

[7] Jacques Freixinos. Toulouse. Histoire panoramique de la Révolution à la seconde guerre mondiale 1789-1939. Toulouse, L'Auta, 2019.

[8] Philippe Gambette and Jean Véronis. Visualising a text with a tree cloud. In Classification as a Tool of Research, Proc. of IFCS'09 (11th Conference of the International Federation of Classification Societies), pages 561-570, 2010.

[9] Marjorie Guillin. L'académie royale de peinture, sculpture et architecture de toulouse : les hommes et leurs réseaux. Les papiers d'ACA-RES, Actes des journées d'étude, 2016.

[10] Coralie Machabert. La situation des artistes figuratifs dans le foyer artistique toulousain au cours des années 1950. In Catherine Wermester (dir.), "On me traite au mieux comme un monument ». (Otto Dix, 1951). Le sort des artistes figuratifs dans les années 1950, pages 46-61, 2018.

[11] Coralie Machabert. La vie artistique à Toulouse (arts plastiques) de 1939 à 1958 . PhD in art history dir. Luce Barlange and Jean Nayrolles, Université Toulouse 2, 2019, 2019.

[12] Raymonde Moulin. Les bourgeois amis des arts. les expositions des beaux-arts en province, 1885-1887. Revue française de sociologie, 17(3):383-422, 1976.

[13] Zeliha Ozcan. La Société des Artistes Méridionaux de 1980 à nos jours. mémoire de Master 2, Université Toulouse-Le Mirail, 2012.

[14] Stéphanie Putaggio. La Société des Artistes Méridionaux, 1955-1960 : tentative de redéfinition de l'art produit en région toulousaine. mémoire de Master 1, Université Toulouse-Le Mirail, 2012.

[15] Léa Saint-Raymond. Bordeaux vs. paris: An alternative market for local and independent artists? Arts, 9(4), 2020.

[16] Stéphanie Trouvé. Peinture et discours. La construction de l'école de Toulouse, XVIIe-XVIIIe siècles. Rennes, PUR, 2016.

[17] M. Vachon and al. Société des Artistes méridionaux. Exposition industrielle internationale Commerce, Agriculture, Sciences, Beaux-Arts : mai-septembre 1908. Toulouse, imp. DouladourePrivat, 1908.

[18] Sophie Vinel. Arbus, Alet, Fauré, Soutiras... : Décorateurs toulousains du XXe siècle. Paris, Les Editions de l'Amateur, 2007. 